\title{
AN EFFICIENCY LENS ON THE POWER FIVE CONFERENCES
}

\author{
Jeffrey J. Fountain, Nova Southeastern University, Fort Lauderdale, Florida, U.S.A. \\ Peter S. Finley, Nova Southeastern University, Fort Lauderdale, Florida, U.S.A. \\ Ravi R. Chinta, Nova Southeastern University, Fort Lauderdale, Florida, U.S.A.
}

dx.doi.org/10.18374/JABE-19-3.2

\begin{abstract}
The purpose of this paper was to investigate the financial efficiency of the athletic departments in the Power Five conferences as it relates to total athletic department expenditures compared to the overall athletic department "on-field" success over a long period of time. Thirteen years' worth of both financial and performance data was collected on all 65 athletic departments currently in the NCAA's Power Five Conferences. Using Data Envelope Analysis (DEA) this study produced DEA models that showed how efficient each athletic department was over the past 13 years when analyzing expenditure inputs to the output measurement of overall athletic success. The longitudinal nature of this study combined with the use of multiple DEA models along with cluster analysis produced unique findings on the efficiency of Power Five athletic departments in the context of overall athletic success. The results show that only two athletic departments in the Power Five Conferences were deemed efficient at all three levels of analysis, be it by conference, by strategic cluster, or by all Power Five athletic departments as a single group over a long period of time. The results also provide efficiency scores for each Power Five Conference athletic department, which allows for comparison between university athletic departments in the Power Five Conferences. This type of efficiency analysis could provide university administrators with additional useful information when evaluating their athletic department's overall performance from a financial standpoint to ensure the scarce resources provided to athletics is not going to waste.
\end{abstract}

Keywords: Data Envelope Analysis, Financial Efficiency, College Sports, Power Five, Athletic Success, NCAA 